\title{
NON-TWINING MILKWEED VINES OF OKLAHOMA: AN OVERVIEW OF MATELEA BIFLORA AND MATELEA CYNANCHOIDES (APOCYNACEAE)
}

\author{
Angela McDonnell \\ Botany Department \\ Oklahoma State University \\ 301 Physical Sciences \\ Stillwater, OK 74078 \\ (608) 698-1217 \\ angela.mcdonnell@okstate.edu
}

Key words: distribution, ecology, morphology, taxonomy

\begin{abstract}
Matelea (Apocynaceae, Asclepiadoideae) is a genus of approximately 225 species in milkweed subtribe Gonolobinae. This New World genus is predominantly found in tropical to subtropical regions and is represented in Oklahoma by four species. Two of these, $M$. biflora and $M$.

cynanchoides, are closely related, non-twining perennial herbs that have long confused amateur and professional botanists alike due to similar morphological features. This paper includes a brief review of their taxonomic history and describes the morphology, ecology, and distribution of these species in Oklahoma and neighboring states. Photographs, a distribution map, and a key to the species of Matelea in Oklahoma are included.

\section{INTRODUCTION}

Milkweeds in Oklahoma from Apocynaceae subfamily Asclepiadoideae (the former Asclepiadaceae) display an array of diversity. Species include erect and prostrate herbs and herbaceous vines in five genera (Asclepias L., Cynanchum L., Funastrum E. Fourn., Gonolobus, and Matelea Aubl.). In addition to variation in growth form, they exhibit a variety of corolla forms and variation in the distinctive features of the milkweed subfamily: fusion of male and female floral whorls forming a gynostegium, and an additional floral whorl, the corona.

Matelea is a large genus of approximately 225 species in the milkweed subtribe Gonolobinae. This New World genus consists mostly of vines and is found in tropical and subtropical regions. Matelea is known to be broadly polyphyletic (i.e., consisting of multiple lineages that are not necessarily closely related) and is a good

candidate for taxonomic dissolution (Krings, Thomas, and Xiang 2008; Parks 2008; McDonnell and Fishbein, in prep). In Oklahoma, Matelea is represented by four species that form two morphologically distinct pairs; Matelea baldwyniana (Sweet) Woodson and Matelea decipiens (Alexander) Woodson are vines most common in the eastern part of the state, and Matelea biflora (Nutt. ex Raf.) Woodson and Matelea gynanchoides (Engelm. and A. Gray) Woodson are prostrate to decumbent species, present throughout much of the eastern two-thirds of the state. Pending additional phylogenetic and morphological study, the four species will likely be placed in two genera, distinct from Matelea in the strict sense, which will be restricted to species native to Central and South America.

One of these Oklahoman Matelea species pairs, the non-twining herbaceous species M. biflora (Figs. 1A, 1C) and
\end{abstract}


M. cynanchoides (Figs. 1B, 1D), are closely related and possess similar morphological features. Both species currently reside in Matelea subgenus Chthamalia, a group of approximately 30 milkweeds that are apparently adapted to arid habitats, have a center of diversity in northern Mexico, and are the focus of my dissertation research. This paper will clarify the taxonomic history and morphological differences between the species and will also provide a key to identify the species native to Oklahoma.
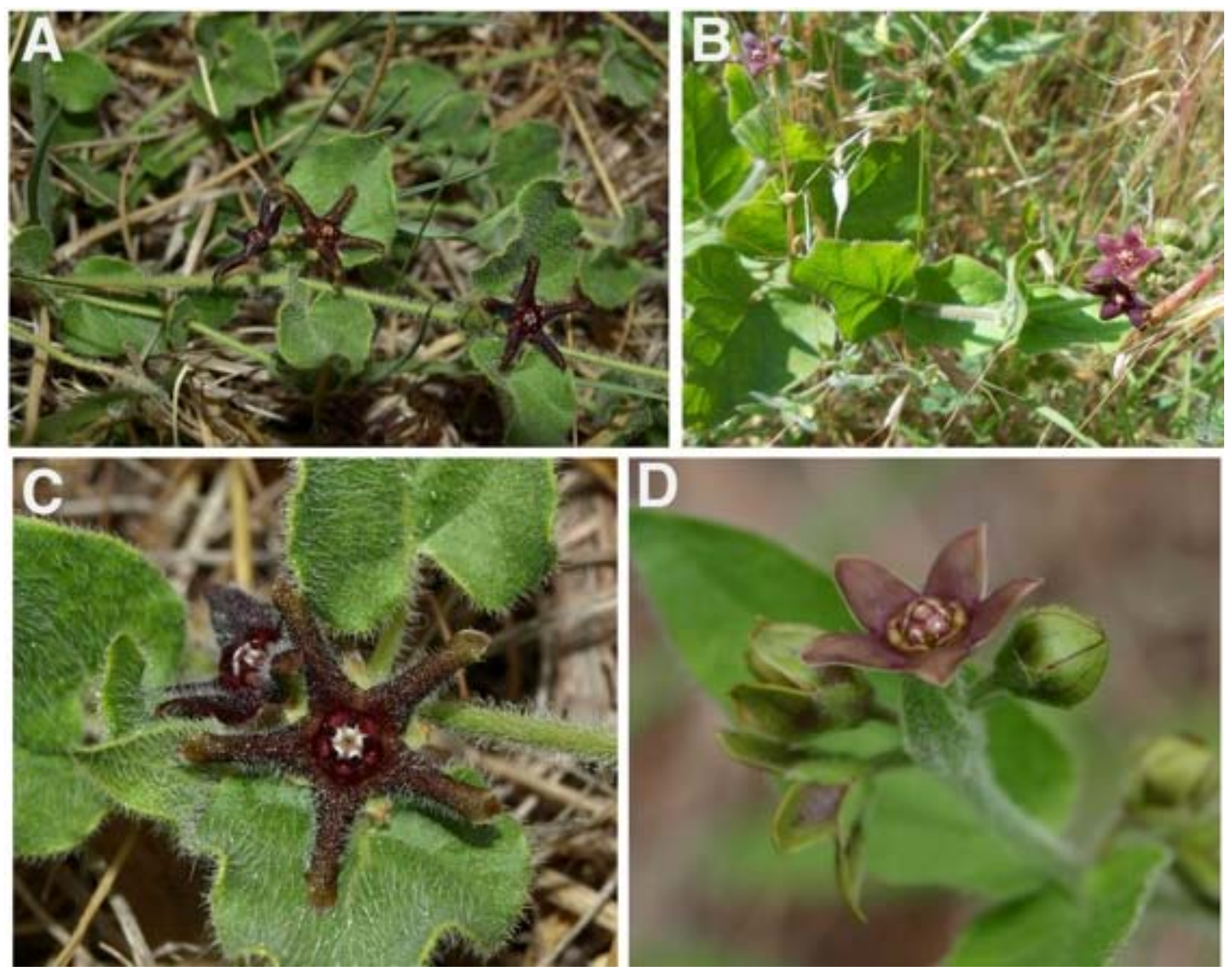

Figure 1 Matelea biflora and Matelea cynanchoides. (A) M. biflora habit, note prostrate stem. Photo by Mark Fishbein. (B) M. cynanchoides habit, note decumbent-ascending stem. (C) M. biflora flowers, note pubescent corolla and reflexed corolla margins. (D) M. cynanchoides flowers and buds, note glabrous corolla and planar corolla margins. Photo by Mark Fishbein. 


\section{METHODS}

Specimen records (336 total, 205 of which were viewed, see appendix for list of viewed specimens) for Matelea biflora and $M$. cynanchoides were downloaded from online data repositories including: the Global Biodiversity Information Facility (GBIF http://www.gbif.org); Tropicos (http://tropicos.org); SEINet (http://swbiodiversity.org/portal/index.ph p); and herbarium websites, such as the Oklahoma Vascular Plants Database (OVPD http://www.oklahomaplantdatabase.org). Specimen loans (abbreviations follow Thiers [2014]) were obtained from the US National Herbarium (US), the New York Botanical Garden (NY), the Missouri Botanical Garden (MO), Harvard University Herbaria (A, ECON, GH), Arizona State University (ASU), University of Texas at Austin (TEX, LL), Kansas State University (KSC), University of Arizona (ARIZ), University of New Mexico (UNM), and Louisiana State University (LSU). Specimens at the Oklahoma State University Herbarium (OKLA), Botanical Research Institute of Texas (BRIT), Sul Ross State University (SRSC), and the University of Oklahoma (OKL) were examined on visits to those herbaria. Additional data were obtained from my field collections and the unaccessioned collections and database of Mark Fishbein (Oklahoma State University). Occurrence data were curated manually to confirm or change species identifications and for georeferencing. The resulting specimen database was used to plan fieldwork across the range of each species. Fieldwork in Oklahoma and Texas was carried out in the summers of 2011, 2012, and 2013. For each population located in the field, specimens were collected and the following data recorded: latitude and longitude coordinates obtained with a handheld GPS device (usually a Garmin ${ }^{\circledR}$ GPSMAP 76), elevation obtained by GPS and checked in Google Earth ${ }^{\circledR}$, substrate, relative local abundance, vegetation type, co-occurring species, occurrence of interacting arthropods (flower visitors and herbivores), and morphological notes.

Specimens obtained from loans and field collections were used for morphological study. Measurements of floral and vegetative characters were carried out using Olympus ${ }^{\circledR}$ cellSens Entry 1.6 imaging software and an Olympus ${ }^{\circledR}$ SZX10 dissecting microscope outfitted with an Olympus ${ }^{\circledR}$ SC30 CMOS color camera. A distribution map (Fig. 2) for both species was produced using a combination of Google Earth ${ }^{\circledR}$, Adobe ${ }^{\circledR}$ Illustrator, and Adobe ${ }^{\circledR}$ Photoshop software. The points on the map include specimens examined and records downloaded from databases for which specimens were not examined. Due to imprecise locality data, not all records could be accurately mapped. Records with ambiguous or incomplete locality data were excluded. 


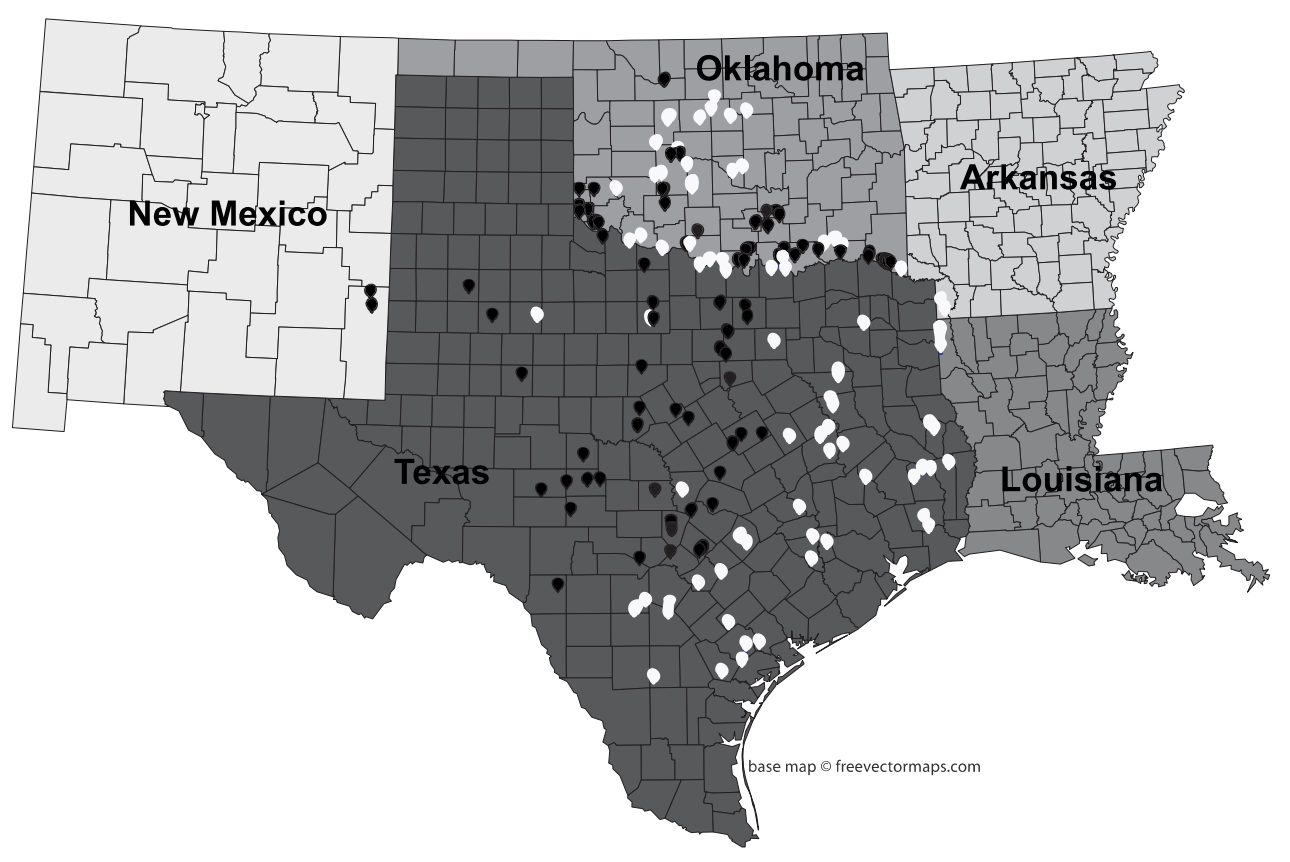

Figure 2 Distribution map showing ranges of Matelea biflora (black) and M. cynanchoides (white)

RESULTS AND DISCUSSION

\section{Matelea biflora (Nutt. ex Raf.) Woodson}

Gonolobus biflorus Nutt. ex Raf.

Gonolobus biflorus Nutt. ex Torr., nom. illeg.

Chthamalia biflora (Nutt. ex Raf.) Decne.

Gonolobus biflorus Nutt. ex Raf. var. wrightii A. Gray

Purple milkweed vine, star milkvine, twoflowered milkvine

\section{Taxonomic History}

The type specimens of what would eventually be named Matelea biflora (see Figs. 1A, 1C) were collected by intrepid English botanist Thomas Nuttall near the Red River in the Arkansas Territory during his travels between October 2, 1818, and February 18, 1820. The collection date was not recorded by the collector or by subsequent taxonomists working with the material. The specimens were probably collected in the summer of 1819, the only time during his trip when flowering specimens were likely abundant. At the time, the Arkansas Territory included all of present day Arkansas and most of present day Oklahoma (the northernmost counties and the panhandle of Oklahoma were excluded). According to his journal and the interpretations of later scholars, Nuttall doesn't appear to have crossed the border into Texas, which was then owned by Spain. The specimens were likely collected on the Oklahoma side of the Red River, in either Choctaw or McCurtain County (Lottinville 1980; Tyrl and Shryock 2014). The specimens were labeled in Nuttall's handwriting "Gonolobus *biflorus Nutt". The asterisk denotes his convention of marking a species name as new (McLean 1980; Stuckey 1966).

Many of the Gonolobus biflorus specimens Nuttall collected received additional labels and were distributed to several herbaria. Currently, there are at least eight duplicate 
sheets held at herbaria of the Academy of Natural Sciences, Philadelphia (PH); Royal Botanic Gardens, Kew (K); Smithsonian Institution (US); and the New York Botanical Garden (NY). Significantly, G. biflorus was never mentioned in Nuttall's Collections towards a Flora of the Territory of Arkansas (1837), the publication in which he describes many new taxa from the region, nor in any of his other publications. Thus, the name indicated as new on Nuttall's labels was never published by him. Like other species discovered and named but not published by Nuttall, G. biflorus was apparently validated by John Torrey (1859) in his Report on the United States and Mexican Boundary Survey. Therefore, some sources cite the authority for this species as $G$. biflorus Nutt. ex Torr.

However, even before Nuttall's (1837) report on the flora of the Arkansas Territory was published, Constantine Samuel Rafinesque, a self-educated professor of botany and natural history who elicited considerable controversy from his contemporaries (Boewe 2003; Warren 2004), published a New Flora of North America (1836). In this work, Rafinesque was the first to describe and validly publish Gonolobus biflorus from a specimen he saw at the herbarium of Zaccheus Collins, a Philadelphia merchant and avid collector of herbarium specimens. According to correspondence held by the American Philosophical Society, the two men were friendly and discussed botanical findings, travels, reading habits, and finance (Collins 1805-1827, Redfield 1876). In 1833, two years after Collins' death, most of his herbarium was sold to Rev. Lewis David von Schweinitz, and a small portion of the collection was sold to Rafinesque shortly thereafter (Stuckey 1971). Rafinesque does not describe the morphology of the specimen in his publication. He also fails to cite the collector of the specimen he studied. He does state that the plant is from "the Red River in Arkanzas and Texas", nearly the precise locality from which Nuttall collected, except for the inclusion of Texas. However, there are no records showing that Nuttall traveled in Texas. Notably, Rafinesque used the exact epiphet, "biflora" indicated by Nuttall on the slips accompanying his specimens.

Collins seems to be the link between Rafinesque and Nuttall. Nuttall named the Plantaginaceae genus Collinsia for him in 1817 and called Collins "a gentleman whose talents as a botanist and a mineralologist are deservedly acknowledged". During Nuttall's trip to the Arkansas Territory, he and Collins exchanged letters (Lawson 2004), and after the trip, Collins received a complete set of duplicates (Stuckey 1971). Rafinesque must have examined the $G$. biflorus specimen Nuttall sent to Collins between 1820 and 1833. Apparently having realized that the name for this species had not been published, Rafinesque seized the opportunity.

Later workers have variably indicated either Nuttall or Rafinesque as the author of G. biflorus. It is not clear whether crediting Nuttall as the author was a repeated accident or an intentional snub toward Rafinesque. Eight years after Rafinesque's publication of G. biflorus, Decaisne (1844) included the species in his newly described genus, Chthamalia Decne., citing Nuttall as the author of the basionym. Asa Gray also cited the species with Nuttall as the author in his Synoptical Flora of North America (1878).

More than 120 years after Nuttall's specimen was first collected, milkweed specialist Robert Everard Woodson, Jr. lumped Chthamalia, including Chthamalia biflora, into the genus Matelea, along with over 100 species in more than 20 genera (Woodson 1941). Currently, floras and databases indicate the authorship of this species as either $M$. biflora (Nutt.) Woodson or M. biflora (Raf.) Woodson. However, because Nuttall did not validly publish Gonolobus biflorus, and because Rafinesque, when validly publishing $G$. biflorus had 
apparently taken up the name suggested by Nuttall, the proper authorship is G. biflorus Nutt. ex Raf. and in Matelea, M. biflora (Nutt. ex Raf.) Woodson.

\section{Species description}

Plants prostrate, usually with 5-20+ stems from a thickened taproot, stem length in flower 10-50 cm, lengthening in fruit, malodorous throughout; the largest leaves with petioles $0.7-2.5 \mathrm{~cm}$ long, blades broadly lanceolate to broadly ovate or nearly triangular, $1.5-5.0 \mathrm{~cm}$ long and $1.0-3.2 \mathrm{~cm}$ wide, bases deeply to shallowly cordate, apices acute, youngest leaf bases with a pair of rounded colleters; inflorescences of axillary pairs or solitary flowers; peduncles 0-10 mm; pedicels $0.2-1.1 \mathrm{~cm}$; calyx lobes ovate to triangular, $2.0-3.5 \mathrm{~mm}$ long; corolla shallowly campanulate-rotate usually with spreading lobes, maroon to dark brown, 8$13 \mathrm{~mm}$ in diameter, deeply 5-lobed; lobes elliptic to narrowly deltoid, margins often reflexed at maturity, densely pilose adaxially and sparsely pilose abaxially; corona consisting of a fleshy disk arising at the junction of the gynostegial column and the corolla, with 5 fleshy, incurved lobes, maroon to dark brown, approximately triangular in cross section, incumbent on anthers; anthers with entire, white, membranous, apical appendages; fruit a muricate, ellipsoid follicle, 5-10 cm long, protuberances numerous $(\geq 5$ per $5 \mathrm{~cm}$ of follicle length).

\section{Distribution and Ecology}

Matelea biflora has been found most commonly on or adjacent to the Edwards Plateau in Texas. The range extends north to the Glass (Gloss) Mountains in Major County, Oklahoma. The easternmost collection was made near Idabel in McCurtain County, Oklahoma. The western edge of its range is near the Texas-New Mexico state line, where two specimens have been collected from Lea County, New
Mexico (see Fig. 2). In Oklahoma, M. biflora is most commonly found south of I-40 in the southern tier of counties, particularly in areas with shale, dolomite, gypsum, limestone, or sandstone substrates (USGS 2005). It is also found west of Oklahoma City in Comanche, Caddo, Canadian, and Major counties on sandstone, shale and limestone. To the southeast of Oklahoma City, it has been collected in Murray, Pontotoc, Johnston, and Carter counties on limestone, shale and conglomerates. In the proximity of the Ouachita Mountains, it has been collected on shale and limestone.

Matelea biflora is generally found on hillsides or plains, in intact or disturbed prairies, pastures, ditches, or roadsides, where the soils generally include clay, rocks and sand. Due to its prostrate, highly branched growth form, $M$. biflora tolerates mowing quite well and is often locally common when found in mown habitats. Among the Level III ecoregions of Texas and Oklahoma (Griffith et al. 2004; Woods et al. 2005), this species has been collected in parts of the High Plains, the Central Great Plains, and the Cross Timbers. It is also found throughout the Edwards Plateau ecoregion of Texas (Griffith et al. 2004). Within Oklahoma, M. biflora is also found within the South Central Plains ecoregion (Woods et al. 2005).

Few collectors have noted associated species; however, available data suggest that these are numerous and diverse. They include graminoids in the genera Aristida, Bothriochloa, Boutelona, Bromus, Carex, Dicanthelium, Erioneuron, and Poa. Other herbaceous associates include species of Aphanostephanus, Asclepias, Ambrosia, Artemisia, Atriplex, Centaurea, Callirhoe, Calylophus, Chrysopsis, Croton, Cuscuta, Dalea, Desmanthus, Euphorbia, Gaillardia, Grindelia, Hedeoma, Hedyotis, Hymenoxys, Krameria, Lesquerella, Linum, Melampodium, Opuntia, Plantago, Ruellia, Solanum, Salvia, Stillingia, Teucrium, Thamnosma, Thelesperma, and Tragia. 
Woody associates include species of Juniperus, Prosopis, Quercus, and Ziriphus.

Though almost nothing is known about faunal interactions with $M$. biflora, including potential pollinators, I have observed dung beetles in the genus Euphoria on flowers twice, but with no pollinia attached (these have also been observed by Mark Fishbein, pers. comm.). Near Fort Worth, Texas, I have observed blister beetles from the family Meloidae on the foliage. Additionally, I've seen a variety of ants and flies on and around flowers.

\section{Matelea cynanchoides (Engelm. \& A. Gray) Woodson}

Gonolobus cynanchoides Engelm. \& A. Gray Vincetoxicum cynanchoides (Engelm. \& A. Gray) A. Heller

Prairie milkvine

\section{Taxonomic History}

Matelea cynanchoides (see Figs. 1B, 1D) was first described as Gonolobus cynanchoides by George Engelmann and Asa Gray in 1845. Ferdinand Lindheimer collected the type specimen during his second collecting trip in Texas in 1844. The holotype is held at MO. There are also four duplicates: one at $\mathrm{K}$, two at $\mathrm{GH}$, and one at University of Michigan (MICH). According to the accompanying label, the specimen was collected in "Sandy soil, in open woods, near Industry. April-June". Lindheimer was contracted by Engelmann and Gray to collect specimens in Texas, and many new species discovered by Lindheimer were described by these two leading botanists of their time (Blankinship 1907). On the 1844 collecting trip, Lindheimer traveled from the Brazos River, near San Felipe, to Industry and then west to the Colorado River. Industry, where the specimen was collected, is a small community in Austin County between the cities of Austin and Houston. In the introductory remarks to Engelmann and Gray's (1845) published enumeration of Lindheimer's collections, they noted this region had rocks of secondary sandstone, cacti, and prairies with large numbers of anthills.

The morphology of G. cynanchoides was described by Engelmann and Gray as follows: "Stems 6 to 15 inches high, diffuse; leaves 1-2 inches long, cordate, with an open sinus, the uppermost sometimes almost truncate at the base. Corolla greenish purple, about two lines [i.e., 0.2 in] in diameter". They also described the coronal structure and pollinia characters in some detail. Interestingly, they concluded that this taxon is a likely congener of Decaisne's Chthamalia biflora (= Matelea biflora, see above). Gonolobus cynanchoides was differentiated primarily by its glabrous corolla. Engelmann and Gray did not take up Decaisne's (1844) generic name, Chthamalia, published the previous year, because they argued that the characters possessed by $G$. cynanchoides were accommodated by the range of variation in Gonolobus, as understood by botanists of that time, including Decaisne. Thus, they rejected Decaisne's concept of Chthamalia as a genus (Decaisne 1844; Engelmann and Gray 1845) and maintained the morphological diversity housed within Gonolobus.

After the initial description of $G$. yynanchoides, Amos Arthur Heller transferred the species to the genus Vincetoxicum (Heller 1900). In doing so, he adopted a then current taxonomic opinion that Vincetoxicum was the correct generic name for Gonolobus, but this opinion was overturned a few decades later. Just under 100 years after the first $G$. cynanchoides specimens were collected, Woodson (1941) placed G. gynanchoides into Matelea (along with many other species, including $M$. biflora).

\section{Species description}

Plants erect, decumbent or prostrate, usually with 3-10+ stems from a thickened 
taproot, stem length in flower $20-40 \mathrm{~cm}$, lengthening in fruit, malodorous throughout; the largest leaves with petioles $0.7-1.3 \mathrm{~cm}$ long, blades broadly ovate to deltoid, 1.5-4 cm long and 1.5-3.2 cm wide, bases truncate to deeply cordate or sagittate, apices acute to rounded, youngest leaf bases with 2-4 elongated, pointed colleters; inflorescences of axillary (sometimes appearing terminal) fascicles or shortly pedunculate umbels; peduncles $0-13 \mathrm{~mm}$; pedicels 3-6 $\mathrm{mm}$ long; calyx lobes ovate to elliptic, 2-3 mm long; corolla shallowly campanulate-rotate, usually with ascending lobes, green to maroon or dark brown, 6-9 $\mathrm{mm}$ in diameter, 5-lobed; lobes ovate to deltoid, margins not reflexed at maturity, glabrous to sparsely pilose adaxially and glabrous abaxially; corona consisting of a fleshy disk arising at the junction of the gynostegial column and the corolla, with 5 fleshy incurved lobes, green, yellow, or maroon, approximately rhombic in cross section, incumbent on anthers, anthers with lobed, white, membranous, apical appendages; fruit a sparsely muricate, broadly ellipsoid follicle, $7-10 \mathrm{~cm}$ long, protuberances few ( $\leq 3$ per $5 \mathrm{~cm}$ of follicle length).

\section{Distribution and Ecology}

Matelea cynanchoides is most commonly found along the Gulf Coastal Plain in Texas. The distribution extends northward to Oklahoma and is strongly associated with Quaternary dunes and alluvial deposits, especially those near the Red, Canadian, and North Canadian Rivers (USGS 2005). To the east, the range of $M$. cynanchoides extends to Miller County in the southwest corner of Arkansas and Caddo Parish in the northwest corner of Louisiana. To the west, this species largely circumvents the Edwards Plateau in central Texas, but does reach isolated outposts in Kent County in northcentral Texas, where a specimen was collected from a sand sheet deposit. It has also been found at an isolated site in Greer
County, Oklahoma, where it is associated with terraces of the North Fork of the Red River, near Lake Altus-Lugert (see Fig. 2). Along both sides of the Red River, $M$. cynanchoides populations are found on alluvial deposits (mostly Cretaceous sands) intercalated between $M$. biflora populations that occur along upland bluffs on sedimentary substrates. Populations in southern and eastern Texas are found on various sandy deposits that include Queen City sand, Carrizo sand, the Lissie formation, the Willis formation, and the Catahoula formation as well as mudstone, sandstone, siltstone, and alluvium.

Matelea cynanchoides is typically found in openings in cross timbers and pine-oak forests and in prairies. It is strongly associated with stabilized dune systems. This species tolerates disturbance and is regularly found in weedy sites along roads, in pastures, and other deforested areas. Unlike its congener, this species is decumbent-upright, but it seems to recover well from the effects of mowing by producing branches from the base or from low axillary buds. In Texas and Oklahoma, M. cynanchoides has been well collected from two Level III ecoregions (Griffith et al. 2004; Woods et al. 2005): the South Central Plains and the East Central Texas Plains. The westernmost collection of $M$. cynanchoides is from a sand sheet near the Lubbock area, in the High Plains ecoregion. There are also many collections from within the Western Gulf Coastal Plains ecoregion of Texas (Griffith et al. 2004). In Oklahoma, M. cynanchoides also occurs in the Central Great Plains and the Cross Timbers (Woods et al. 2005).

Though few specimens record associated species, available data suggest that the associated species are numerous and diverse. These include graminoids in the genera Aristida, Cenchrus, Dichanthelium, Digitaria, Eragrostis, Eustachys, Panicum, Paspalum, and Sporobolus. Other herbaceous associates include species of Acalypha, 
Aristolochia, Asclepias, Berlandiera, Chenopodium, Cnidoscolus, Croton, Commelina, Dalea, Diodia, Ditaxis, Erigeron, Eriogonum, Eupatorium, Gaillardia, Galactia, Helenium, Helianthus, Heliotropium, Hymenopappus, Hypericum, Indigofera, Lantana, Lepidium, Mimosa, Monarda, Opuntia, Phyllanthus, Physalis, Richarida, Rudbeckia, Sida, Sphaeralcea, Stillingia, Tetragonotheca, Triodanis, Verbena, Vernonia, and Yucca. Woody associates include species of Callicarpa, Carya, Celtis, Diospyros, Juniperus, Pinus, Prosopis, Prunus, Quercus, Rhus, Vaccinium, and Vitis.

There are no known pollinators or other faunal interactions for M. gynanchoides, but there has been one observation (Fishbein, pers. comm.) of a small, unidentified weevil (Curculionidae) visiting the flowers, apparently feeding on nectar.

\section{ACKNOWLEDGEMENTS}

Funding from the Oklahoma State University Department of Botany McPherson Fund, the Oklahoma State University Botanical Society, the Society of Systematic Biologists, and the Systematics Research Fund of the Linnaean Society has made this research possible. I thank Dr. Mark Fishbein, whose expertise and dedication to milkweed research have been invaluable in all aspects of this project. I thank Ben Haack, Kevin McDonnell, Bob O'Kennon, and Lindsey Worcester, who each provided exceptional field support and assistance. I also thank an anonymous reviewer for comments and suggestions that greatly improved this manuscript. Finally, I thank the collections managers and curators of each herbarium that I have worked with: ARIZ, ASU, BRIT, CAS, GH, KSC, LSU, MO, NY, OCLA, OKL, OKLA, SRSC, TEX/LL, UNM, and US.

\section{REFERENCES}

Blankinship, J.W. 1907. Plantae Lindheimerianae. Part III. Missouri
Botanical Garden Annual Report 1907.

pp. 123-223.

Boewe, C. 2003. Profiles of Rafinesque. Knoxville: The University of Tennessee Press.

Collins, Z. 1805-1827. Correspondence with various botanists. Philadelphia Academy of Natural Sciences. Coll. 129.

Correll, D.S. and M.C. Johnston. 1970. Manual of the V ascular Plants of Texas. Renner (TX): Texas Research Foundation.

Decaisne, J. 1844. Asclepiadeae. In A. P. De Candolle (ed.). Prodromus Systematis Naturalis Regni Vegetabilis.. Vol. 8. pp. 490-665. Paris: Masson.

Engelmann, G. and A. Gray. 1845. Plantae Lindheimerianae: An Enumeration of $F$. Lindheimer's Collection of Texan Plants. With Remarks, and Descriptions of New Species, Etc: Freeman and Bolles.

Gray, A. 1878. Synoptical Flora of North America. Vol. II - Part I. Gamopetalae after Compositae. New York: Ivison, Blakeman, Taylor, \& Co.

Griffith, G.E., S.A. Bryce, J.M. Omernik, J.A. Comstock, A.C. Rogers, B. Harrison, and D. Bezanson. 2004. Ecoregions of Texas (color poster with map, descriptive text, and photographs). Reston (VA): U.S. Geological Survey.

Heller, A.A. 1900. Some changes in nomenclature. Mublenbergia 1(1): 1-8.

Krings, A., D.T. Thomas, and Q.-Y. Xiang. 2008. On the generic circumscription of Gonolobus (Apocynaceae, Asclepiadoideae): Evidence from molecules and morphology. Systematic Botany 33:403-415.

Lawson, R.M. 2004. The Land Between the Rivers: Thomas Nuttall's Ascent of the Arkansas, 1819. Ann Arbor: The University of Michigan Press.

Lottinville, S. 1980. Editor's introduction $A$ Jounal of Travels into the Arkansas Territory During the Year 1819. (pp. ix-xxiv). Norman (OK): University of Oklahoma Press. 
McLean, E.P. 1980. Asclepiadaceae of Thomas Nuttall at the Academy of Natural Sciences of Philadelphia. Bartonia 47:31-35.

Nuttall, T. 1837. Collections towards a flora of the territory of Arkansas. Transactions of the American Philosophical Society. pp. 139-203.

Parks, M. 2008. Phylogeny of New World Milkweed Vines (Apocynaceae, Gonolobinae) [Master's thesis]. Portland (OR): Portland State University.

Rafinesque, C.S. 1836. New Flora of North America. Vol. IV: Neobotanon. Philadelphia.

Redfield, Mr. 1876. Botanical correspondence of Zaccheus Collins. Proceedings of the Academy of Natural Sciences of Philadelpia 28:81-82.

Stuckey, R.L. 1966. Thomas Nuttall's 1816 Ohio valley plant collections described in his "Genera" of 1818. Castanea 187198.

Stuckey, R.L. 1971. The first public auction of an American herbarium including an account of the fate of the Baldwin, Collins, and Rafinesque herbaria. Taxon 20(4):443-459.

Thiers, B. 2014. Index Herbariorum: A global directory of public herbaria and associated staff. New York Botanical Garden's Virtual Herbarium. http://sweetgum.nybg.org/ih/. Retrieved August 2014.

Torrey, J. 1859. Botany of the Boundary. In W. H. Emory (ed.). Report on the United States and Mexican Boundary Survey. Vol. 2. Washington DC: U.S. Govt.
Tyrl, R.J. and P.A. Shryock. 2014. A cavalcade of field botanists in Oklahoma-contributors to our knowledge of the flora of Oklahoma. Oklahoma Native Plant Record 13:55-100.

Tyrl, R.J., S.C. Barber, P. Buck, W.J. Elisens, J.R. Estes, P. Folley, L.K. Magrath, C.L. Murray, A.K. Ryburn, B.A. Smith, C.E.S. Taylor, R.A. Thompson, J.B. Walker, L.E. Watson. (in prep). Flora of Oklahoma: Keys and Descriptions. Noble (OK): Flora Oklahoma Inc.

USGS (Cartographer). 2005. Preliminary integrated geologic map databases for the United States: Central states: Montana, Wyoming, Colorado, New Mexico, North Dakota, South Dakota, Nebraska, Kansas, Oklahoma, Texas, Iowa, Missouri, Arkansas, and Louisiana. http://pubs.usgs.gov/of/2005/1351/.

Warren, L. 2004. Constantine Samuel Rafinesque: $A$ voice in the American wilderness: Lexington (KY): University Press of Kentucky.

Woods, A.J., J.M. Omernik, D.R. Butler, J.G. Ford, J.E. Henley, B.W. Hoagland, B.C. Moran, 2005. Ecoregions of Oklahoma (color poster with map, descriptive text, summary tables, and photographs). Reston (VA): U.S. Geological Survey.

Woodson, R.E., Jr. 1941. The North American Asclepiadaceae I. Perspective of the genera. Annals of the Missouri Botanical Garden 28:193-244. 


\section{KEY TO THE SPECIES OF MATELEA IN OKLAHOMA}

The following key includes the four species of Matelea native to Oklahoma and a version will appear in the next edition of the Flora of Oklahoma: Keys and Descriptions (Tyrl et al., in prep). Gonolobus is included in the key to aid in distinguishing G. suberosus, which has sometimes been placed in Matelea as M. gonocarpa.

1. Flowers with dorsal anther appendages. Follicles thick-walled, winged. Gonolobus

1. Flowers lacking dorsal anther appendages. Follicles thin-walled, smooth or muricate, but not winged. Matelea

2. Plants non-twining herbs with multiple prostrate to ascending stems from the base, $10-50 \mathrm{~cm}$ long. Leaf blades $1-6 \mathrm{~cm}$ long, conspicuously and generally pubescent. Corolla rotate-campanulate with lanceolate to deltoid lobes.

3. Stems nearly to fully prostrate. Corolla lobes narrowly deltoid to lanceolate, usually spreading, margins reflexed at maturity. Adaxial surface of calyx and corolla with dense, thick hairs.

3. Stems decumbent, ascending, or nearly erect. Corolla lobes deltoid, usually ascending, margins planar. Adaxial surface of calyx and corolla glabrous.

M. cynanchoides

2. Plants vines with 1-few stems from the base, $100-300 \mathrm{~cm}$ long. Leaf blades 6-18 cm long, inconspicuously puberulent with hairs mostly limited to veins. Corolla campanulate with narrowly lanceolate to linear, twisted lobes.

4. Corolla white or cream. M. baldwyniana

4. Corolla maroon or brown-purple. M. decipiens 


\section{APPENDIX}

Specimens of Matelea biflora and M. cynanchoides that were examined are listed below. Data are presented in the following format: taxon: provenance, voucher (acronym of herbarium deposition). Specimens collected by more than one person are listed here by the first name on the label.

Matelea biflora (Nutt. ex Raf.) Woodson

U.S.A., New Mexico: Lea Co.: Hutchins 9411 (NMU), Sivinski 8456 (NMU)

U.S.A., Oklahoma: Bryan Co.: Blain 131 (US), Taylor 608 (OKL), Taylor 1413 (OKL), Taylor 24871 (OKL), Caddo Co.: Magrath 9764 (OCLA, 2 sheets), Nighswonger 1375 (OKL), Hoagland 2909 (OKL), Hoagland 2433 (OKL), Carter Co.: Fryxell 1367 (NY), Goodman 7841 (OKL), Choctaw Co.: Leavenworth s.n. (NY, 2 sheets), Magrath 16036 (OCLA), Comanche Co.: Thompson S0377 (OKL), Cotton Co.: Waterfall 7275 (OKL), Harmon Co.: Stevens 1169 (GH, NY), Waterfall 7784 (OKL), Jackson Co.: Buthod AB-7372 (OKL), Buthod AB-10028 (OKL), Johnston Co.: Taylor 528 (OKL), Love Co.: Taylor 3605 (OKL), Major Co.: Rein 41 (OKLA), Fishbein 6593 (OKLA), McCurtain Co.: Waterfall 17257 (GH, CAS), Demaree 12644 (OKL), Buthod AB-7197 (OKL), Murray Co.: Johnson 67 (OKL), Pontotoc Co.: Goodman 5454 (OKL), Waterfall 11425 (OKL), Johnson PON0154 (OKL), Stephens Co.: Magrath 16541 (OCLA), Tillman Co.: Smith 54 (OKL), County Uncertain: Nuttall s.n. (NY, type), Merrill 301 (US)

U.S.A., Texas: Bastrop Co.: Tharp 1697 (US), Bell Co.: Nesom 6432, Bexar Co.: Harvard 30 (US, GH), Schulz 512 (US), Jermy s.n. (US), Blanco Co.: Prinzie 221 (MO, OKLA), Brown Co.: Carr 12728 (TEX), Rein 40 (OKLA), Comanche Co.: Lehto L25070 (ASU), Concho Co.: Dorr 1563 (TEX), Dallas Co.: Lehto L25114 (ASU), Reverchon 2310 (GH, NY, 4 sheets, US), Bush 623 (GH, NY, 2 sheets, US), Reverchon s.n. (NY, 2 sheets), Bodin 234 (US), Reverchon 619 (US), Denton Co.: Lundell 8423 (GH), Cory 53715 (NY, US), Eastland Co.: Johnston 73 (ASU), Edwards Co.: Cory 39042 (GH), Erath Co.: Hoisington 244 (OKL), Garza Co.: Hutchins 546 (TEX), Wooton s.n. (US), Hamilton Co.: Tharp, s.n. (GH), Holland 10093 (KSC), Hardeman Co.: Ball 1121 (US), Hockley Co.: Thurow s.n. (US), Johnson Co.: Lehto L25208 (ASU), Kerr Co.: Heller 1681 (GH, NY, US), Llano Co.: Bray 336 (US), Lubbock Co.: Wooton s.n. (US), Demaree 7717 (US), Demaree 7699 (US), McLennan Co.: Smith 535 (NY), Prinzie 229 (MO, OKLA), Massey 940 (OKL), Menard Co.: McVaugh 8291 (GH), Rein 38 (OKLA), Mitchell Co.: Tracy 7974 (US, GH, NY, 2 sheets), Schleicher Co.: Turner 21-840 (TEX), Rein 39 (OKLA), Sutton Co.: Cory 39624 (GH), Tarrant Co.: Correll $32752(\mathrm{GH})$, Ruth 93 (KSC, US, 2 specimens, GH, NY, 3 specimens), Cory 54532 (TEX), Carr 12833 (TEX), Pond s.n. (US, NY), Killian 6799 (US), Taylor Co.: Williams s.n. (GH), Tom Green Co.: Tweedy s.n. (NY, US), Travis Co.: Poud s.n. (US), Young s.n. (GH), Carr 11100 (TEX), Tharp 1691 (US), Tharp 1329 (US), Wichita Co.: Whitehouse 10883 (NY), Williamson Co.: Baird 3796 (NY), Wise Co.: McDonnell 150 (OKLA), McDonnell 172 (OKLA), Bridges 13625 (TEX), Young Co.: Vollum s.n. (US, 2 sheets), Cory $13144(\mathrm{GH})$, County Uncertain: Wright s.n. (GH, 2 sheets, NY), Lindheimer s.n. (GH), Wright 545 (GH, 2 sheets), Degener 5050 (NY), Hayes s.n. (NY), Stanfield s.n. (NY), Ward s.n. (NY, US), Stevenson s.n. (US), Bebb 2394 (OKL), Bebb 2508 (OKL) 


\section{Matelea cynanchoides (Engelm. \& A. Gray) Woodson}

U.S.A., Arkansas: Miller Co.: Thomas 134244 (KSC, LSU), Kral 65495 (TEX)

U.S.A., Louisiana: Caddo Parish: MacRoberts 88691 \& 6891 (TEX, LSU, NY, US), Reid 5569 (LSU), Reid 5578 (LSU), Parish Uncertain: Leavenworth s.n. (NY)

U.S.A., Oklahoma: Atoka Co.: Fishbein 6775 (OKLA), Lewallen 2636 (OKL), Rein 56 (OKLA), Rein 57 (OKLA), Blaine Co.: Rein 42 (OKLA), Waterfall 7071 (OKL), Bryan Co.: Taylor 1654 (OKL), Taylor 2294 (OKL), Caddo Co.: Pettijohn 139 (OCLA), Bittle 160 (OKL), Canadian Co.: Goodman 5846 (GH), Goodman 7523 (OKL), Choctaw Co.: Waterfall, 16031 (KSC), Hoagland HUGO396 (OKL), Cleveland Co.: Stevens 1569 (GH), Jeffs s.n. (OKL), Barkley s.n. (OKL), Smith 604 (OKL), Hawk 3 (OKL), Pusonett 16 (OKL), Custer Co.: Waterfall 2226 (OKL), Waterfall 7347 (OKL), Grady Co.: McDonnell 195 (OKLA), Pettijohn 217 (OCLA), Bowers 224 (OCLA), Goin 6 (OCLA), Rein 43 (OKLA), Rein 44 (OKLA), Greer Co.: Joseph s.n. (OKL), Jefferson Co.: Goodman 7198 (OKL), Taylor 3632 (OKL), Kingfisher Co.: Bollenbach 47 (OKL), Folley 330 (OKL), Logan Co.: Carleton 154 (US, KSC), Smith 539 (OKL), Smith 393 (OKL), Marshall Co.: Goodman 5926 (OKL), McCurtain Co.: Schwenn 105 (OCLA), Payne Co.: Stratton 3046 (OKL), Pushmataha Co.: Magrath 11930 (OCLA), Magrath 15549 (OCLA), Magrath 11254 (OCLA), Tillman Co.: Johnson HF0071 (OKL), County Uncertain: Carleton s.n. (KSU), Palmer 182 (NY, US, 2 sheets)

U.S.A., Texas: Anderson Co.: Rein 107 (OKLA), Angelina Co.: Rein 105 (OKLA), Aransas Co.: Berlandier 561 (GH), Atascosa Co.: Orzell 6696 (TEX), Austin Co.: Lindheimer 273 (GH, 2 sheets, type), Bastrop Co.: Lott 5093 (TEX), Lott 4497 (TEX), Bee Co.: Carr 24543 (TEX), Bexar Co.: Thurber 185 (GH), Brazos Co.: Fryxell 2380 (NY), Burnet Co.: Wolff 1551 (US), Cooke Co.: Lusk s.n. (NMU), De Witt Co.: Drushel 10771 (US), Franklin Co.: Worcester 164 (OKLA), Freestone Co.: Thomas 133705 (NY), Frio Co.: Palmer 33883 (NY), Gonzales Co.: Cory 5781 (GH), Cory $8348(\mathrm{GH})$, Bogusch 1873 (US), Goodman 6215 (OKL), Warnock 164 (TEX), Guadalupe Co.: Rein 54 (OKLA), Harris Co.: Hall 520 (GH, US, NY, 2 sheets), Thuron s.n. (US), Henderson Co.: Correll 22110 (NY), Jasper Co.: Orzell 11045 (TEX), Kent Co.: Correll 22110 (NY), Leon Co.: Kral 67245 (GH), Palmer 13418 (US), Limestone Co.: Holmes 7116 (TEX), Navarro Co.: Joor 96 (US), Newton Co.: Allen 22175 (LSU, 2 sheets), Parker Co.: Quayle 566 (TEX), Refugio Co.: Hill 10613 (GH, NY), Shelby Co.: Thomas, 129199 (NY), Tyler Co.: Prinzie 225 (MO, OKLA), Upshur Co.: Holmes 9964 (TEX), Van Zandt Co.: Rein 108 (OKLA), Correll 16211 (GH), Wilbarger Co.: Correll 16211 (GH), County Uncertain: Tharp s.n. (GH), Tharp 566 (NY), Hayes s.n. (NY), Bigelow s.n. (NY), Drummond 203 (NY), Wright s.n. (NY), Wright 545 (GH, 2 sheets) 